INTERDISCIPLINARIA ARCHAEOLOGICA NATURAL SCIENCES IN ARCHAEOLOGY

\title{
The Ancient Greek Potter's Wheel: Experimental Archaeology and Web Applications for Velocity Analysis
}

\author{
Brandon Neth ${ }^{1}$, Eleni Hasaki ${ }^{1 *}$ \\ ${ }^{1}$ University of Arizona, Tuscon, Arizona 85721, United States of America
}

\section{ARTICLE INFO}

\section{Article history:}

Received: $11^{\text {th }}$ February 2021

Accepted: $7^{\text {th }}$ October 2021

DOI: http://dx.doi.org/10.24916/iansa.2021.2.1

Key words:

potter's wheel

ancient Greece

Mediterranean

visualization

velocity measurement

web application

\begin{abstract}
A B S TRACT
The potter's wheel is central to the understanding of ancient technology, knowledge transfer, and social complexity. With scant evidence of potter's wheels from antiquity, experimental projects with replica potter's wheels can help researchers address larger questions on ceramic production. One such set of experiments, performed using the Ancient Greek wheel replica in Tucson modelled on Athenian and Corinthian iconographic evidence, provided useful insight into the qualitative experience of ancient potters. In past experiments, the quantitative analysis of the throwing sessions included data on wheel velocity which had been collected collected over large intervals, comprising entire stages of the throwing process. While this method provides an overview of rotational speed, a continuous velocity graph provides a clearer picture collected data on wheel velocity. To address this, we developed a web application (WheelVis; brandonneth.github.io/wheelvis) to aid in the velocity analysis of experimental potter's wheels. Users provide a recording of the throwing session and while advancing through the recording, they mark points where the wheel has completed rotations. Using the time intervals between these points, the tool reconstructs a graph of the velocity of the wheel throughout the throwing session. This innovative application provides fast, fine-grained velocity information, and helps archaeologists answer questions about the physical properties of their experimental replicas or wheels used in traditional workshops. Future development of the application will include contextual partitions to allow users to split the throw into different stages, enabling further analysis into the throwing process. Moreover, intelligent error detection would notify users when a mark is likely to be made in error and allow them to correct their mistake.
\end{abstract}

\section{Introduction: General trends of potter's wheel research}

As the potter's wheel is central to the operation of a pottery workshop, archaeologists have attempted to extract as much information as possible from the device, the user, and the finished product. In this section, we capture a few of the major aspects that wheel research has covered within the scope of the Greek prehistoric and historical periods. The general trends can be grouped into four major categories:

\subsection{The wheel apparatus}

In this category we consider four subsets:

1) The study of archaeological remains (mostly of wheelheads, as no entire wheel apparatus has survived from Greek antiquity; Evely, 2000; Hasaki, 2019; Rotroff, 2006).

\footnotetext{
*Corresponding author. E-mail: hasakie@email.arizona.edu
}

2) The rather well-known list of two dozen depictions of Athenian, Corinthian, and Boeotian ceramics that depict potters working at the wheel (Hadjidimitriou, 2005; Hasaki, 2019; Stissi, 2002; Vidale, 2002; Williams, 2019) (Figure 1).

3) A small number of Greek and Latin literary references in epics and philosophical works praising the skill and patience of ancient potters, and claiming Athens and Corinth as the birthplaces of the potter's wheel (Cuomo di Caprio, 2017; Hasaki, 2019). Two well-known references attest to the arduous wheel apprenticeship based on observation and participation method:

"Did you never observe in the arts how the potters" boys (sons) look on and help, long before they touch the wheel?" (Plato, Republic 5.467a)

"Is not this, as they say, to learn the potter's craft by undertaking a pithos... and does not this seem to you a foolish thing to do?" (Plato, Gorgias 514e) 


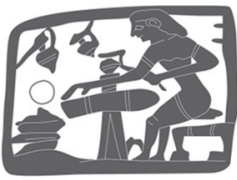

1

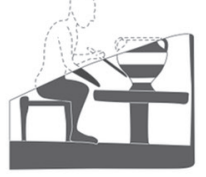

2

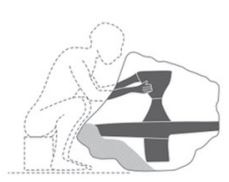

3

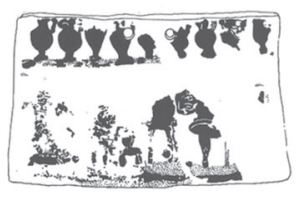

4

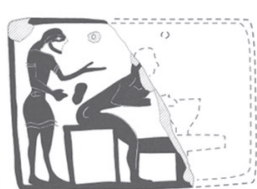

5

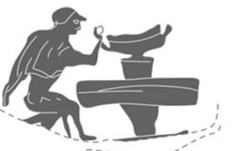

9

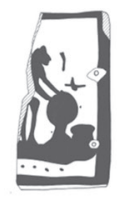

6

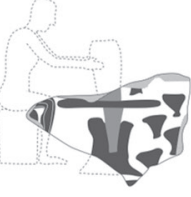

7

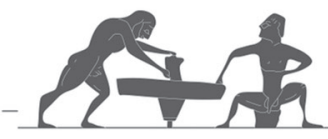

8A-B

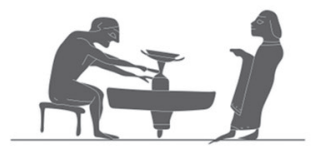

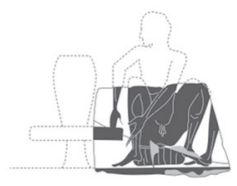

14

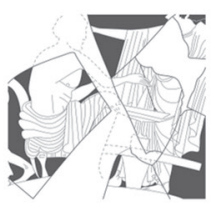

10

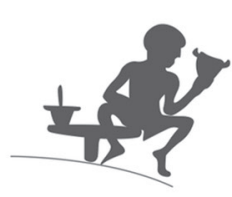

11

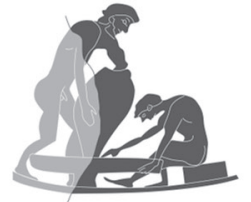

12

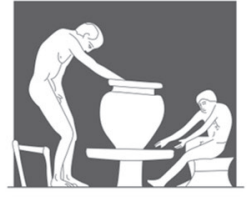

13

Figure 1. Wheel Representations on Corinthian Pinakes from Penteskouphia (1-6) and Athenian and Related Vases (7-17). 1: Paris, Louvre MNB 2857; 2-6: Berlin, Antikensammlung 2: F 868; 3: F 869; 4: F 640+fr.; 5: F 870; 6: F 885; 7: Athens, National Museum, Akr. 1.2579; 8A-B: Karlsruhe, Badisches Landesmuseum 67/90 ; 9: London, British Museum 1847,1125.18 (B 432); 10: Athens, Acropolis Museum GL 166; 11: Athens, National Museum 1114-2624 (442); 12: Munich, Staatliche Antikensammlungen und Glyptothek 1717; 13: Caltagirone, Museo Regionale della Ceramica 1120; 14: Athens, National Museum, Acropolis Collection 1.853; 15: Athens, National Museum, Akr. 2.470; 16: Athens, National Museum, Akr. 2.739; 17: Athens, Ancient Agora PNP 42. All drawings by Y. Nakas (except no. 4 from Zimmer 1982; nos. 5-6 by J. Denkinger). Not to scale. From Hasaki (2019).

These passages also convey successfully the wellstructured framework of potters learning to proceed from smaller to larger vessels in the course of such apprenticeships apprenticeships.

4) The ever-increasing number of experimental replicas of prehistoric and historic wheels (for example, a Minoan-type wheel, or a Classical Athenian potter's wheel; Evely and Morrison, 2010; Hasaki, 2019; Morrison and Park, 2007-2009).

\subsection{The wheel and the finished pot}

To produce a pot, multiple rotary devices and multiple forming techniques are involved. A fast wheel for throwing a pot is just one of the many possible variations. For over 20 years, scholars have worked hard on identifying specific marks left on a pot "thrown on a wheel", situating the potter's wheel within the wider spectrum of rotary devices, from turntables to fast wheels (Eiteljorg, 1980; Courty and
Roux, 1995; Roux and Courty, 1998). A refined terminology for capturing the various combinations of rotary-surface and forming methods has enhanced our understanding of this crucial stage and made us realise how fundamental such distinctions are, as for example the importance of Rotational Kinetic Energy in producing a wheel-thrown pot; (Choleva, 2012; Choleva, 2020). For the Greek ceramics, emphasis has been paid on the turning marks on the underside of pots for establishing the direction (clockwise or counterclockwise) of the ancient Greek wheel (Schreiber, 1983; 1999).

\subsection{The wheel and the potter}

Extensive ethnographic research has focused on the use of a potter's wheel by a potter; with the use of video recordings, computer modelling, and statistical analysis, scholars have expanded the scope of questions to cover topics such as standardization, apprenticeship length and structure (Roux and Corbetta, 1989; Hasaki, 2012; Hasaki, 2019; Langdon, 
Figure 2. Ancient Greek wheel experimental replica in Tucson, post-lowering its height. Laboratory for Traditional Technology, School of Anthropology, University of Arizona.

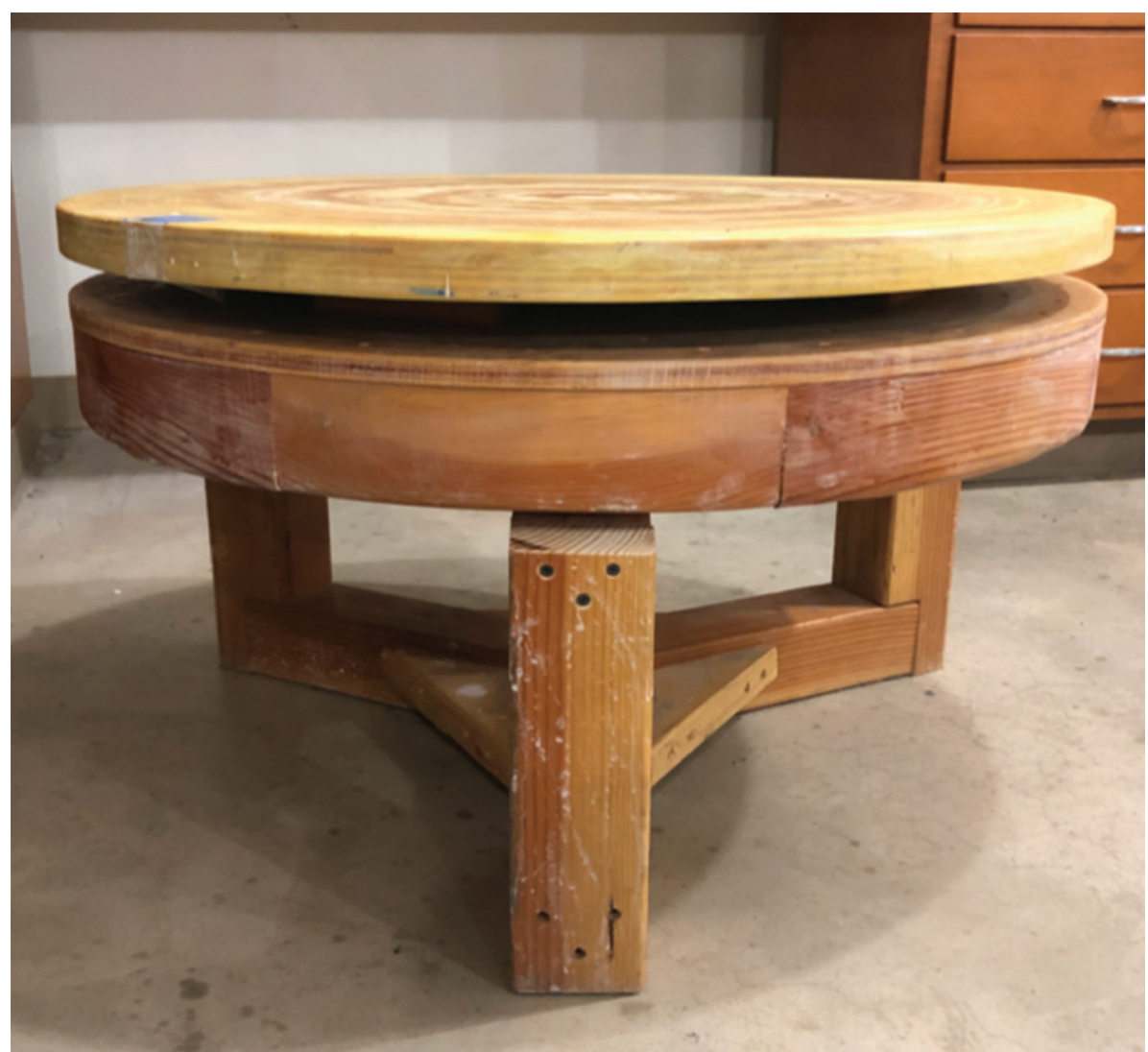

\section{The Ancient Greek wheel replica and experimental sessions}

Shifting our attention to our current project, the Ancient Greek wheel replica started in 2012 as a student project for a course on Ancient Greek Technology in conjunction with the Laboratory of Traditional Technology at the School of Anthropology of the University of Arizona, Tucson (Hasaki, 2019; ltt.lab.arizona.edu/content/greek-wheelproject); Stephen Corcello produced a wheel $1.067 \mathrm{~m}$ in height. Its wheelhead measures $0.81 \mathrm{~m}$ and weighs $27.8 \mathrm{~kg}$. In autumn 2017 the wheel was lowered to $0.53 \mathrm{~m}$ to more accurately reflect the ancient depictions (Figure 1). Its frame is made of oak wood and the wheelhead is made of spruce with polyurethane coating (Figure 2). We held two experimental sessions in 2013-2014, where Dan Pont took detailed measurements of the RPM of the wheel during specific phases. A second set of experiments was conducted in 2017 and both Dan Pont and Brandon Neth were involved, as we were trying to improve both the wheel's performance and our recording methods.

After reducing the height of the wheel, we collected data on the use of the wheel by experienced local potters. One potter had experience with the wheel in both height configurations. In total, eight vessels were formed, using a variety of potterspinner configurations. The first configuration (Experienced) featured only the experienced potter, Andy Iventosh, age 61 (in 2017), who both spun the wheel and threw the vessel. In this configuration, the wet clay on the potter's hand quickly impeded their ability to grasp the wheel. The second

2013; Knappett, 1999; 2004; Knappett and Van der Leeuw, 2014; Roux and Jeffra, 2015; Roux and de Miroschedji, 2009) 
configuration (Experienced/Novice) featured an experienced potter throwing the vessel and a novice spinning the wheel. In this session, Dan Pont, age 24 (in 2017), filled the spinner role. In this configuration, the potter was able to focus more on the process of throwing. However, as the novice spinner did not have experience with throwing pottery, he lacked the implicit understanding of the throwing process. Thus, he would often spin the wheel at an inopportune time, jostling the wheel during delicate moments of the throwing. The third configuration (Experienced/Experienced; Andy Iventosh/ Joni Pevarnik; age 61/59 in 2017 respectively) featured an experienced potter in both roles, one spinning and one throwing. In this configuration, the inopportune jostling was reduced, but the age of the potters (both in their 60s) disallowed sufficient angular velocity for sustained throwing, requiring more spinning. The age of the participants is noted to highlight how extensive experience could compensate for limited physical strength.

While the potters were throwing vessels, we collected two sets of data with two different methods. In the first method, we used a micro digital tachometer (Hangar 9 model) to measure the rotational velocity of the wheel (Hasaki, 2019; section 3 , this study). In the second method, we used video footage, recorded by the authors.

\section{Methodology}

We developed the web application WheelVis (https:// brandonneth.github.io/wheelvis) to aid scholars in collecting and visualizing velocity information for potter's wheels (Figure 3). While physical analysis of wheel remains and qualitative analysis of throwing are undoubtedly useful in understanding the technology and technique of ancient potters, the value of quantitative measures cannot be ignored. Velocity and the related property of momentum are two such measures. Faster, longer, and easier spinning wheels enable potters to produce pieces with less total labour. Thus, when studying the dissemination of technology and technique in a community of potters, these measures play an important role.

WheelVis works by collecting displacement information from its user. By displacement, we refer to the distance through which the wheel has rotated since the previous user input. As the user inputs displacement quantities, WheelVis calculates durations for those displacements using the video timestamps. WheelVis then calculates the average velocity of the wheel over that time period by dividing the displacement amount by the duration. If the wheel has rotated $d$ times between times $t_{0}$ and $t_{1}$, the average velocity is given by the formula $v=d /\left(t_{1}-t_{0}\right)$.

The first step is to record the wheel throwing session. The only strict requirement at this stage is that the video has a mostly unobstructed view of the wheelhead. The video can be from any angle, and the angle can change during the throwing session, as long as the user can compensate for those changes during the later analysis stages. We find that angles greater than horizontal work better, but any angle greater than 30 degrees above horizontal is more than sufficient. While not required, the analysis stages are much

\section{WheelVis: A Web Application for Analyzing Potter's Wheel Velocity}

Created by Brandon Neth

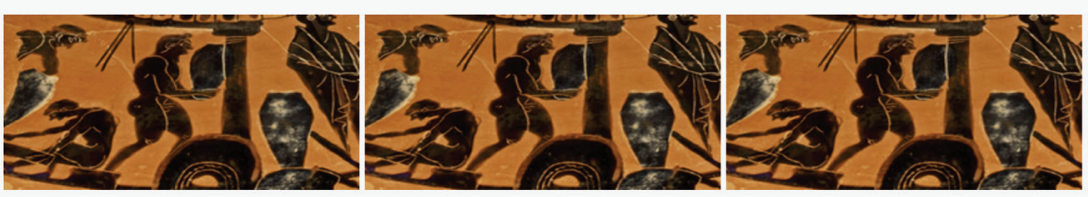

This webpage contains WheelVis, a tool to measure the rotational velocity of wheels by analyzing a video

recording of the wheel spinning. To use the tool, begin

by selecting the video file you want to analyze. The

video should appear in the box below.

Once the video is loaded, the ' $n$ ' key will progress through the video frame by frame. The 's' key will restart the data collection at the current time stamp. Type any number keys to enter numbers. The 'enter' key will submit the entered value. The ' $n$ ' key will submit any entered value and move to the next frame. To export the data as a .csv file, press the 'e' key.

Select a file: choose File no file selected

Entry:

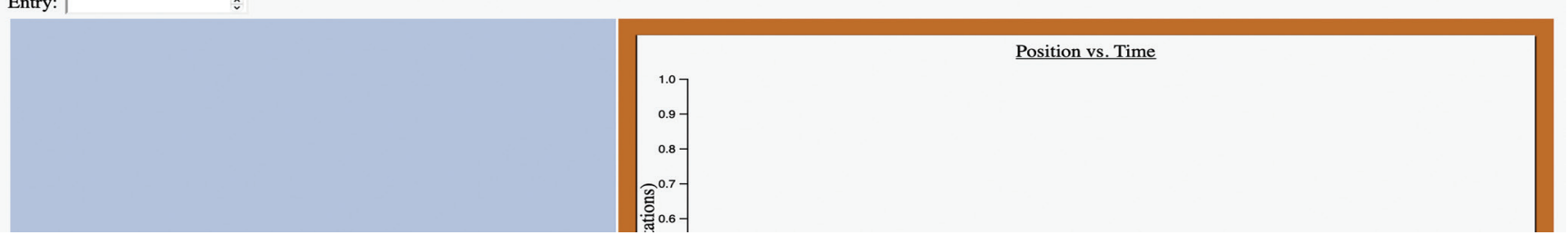

Figure 3. Homepage of WheelVis. 

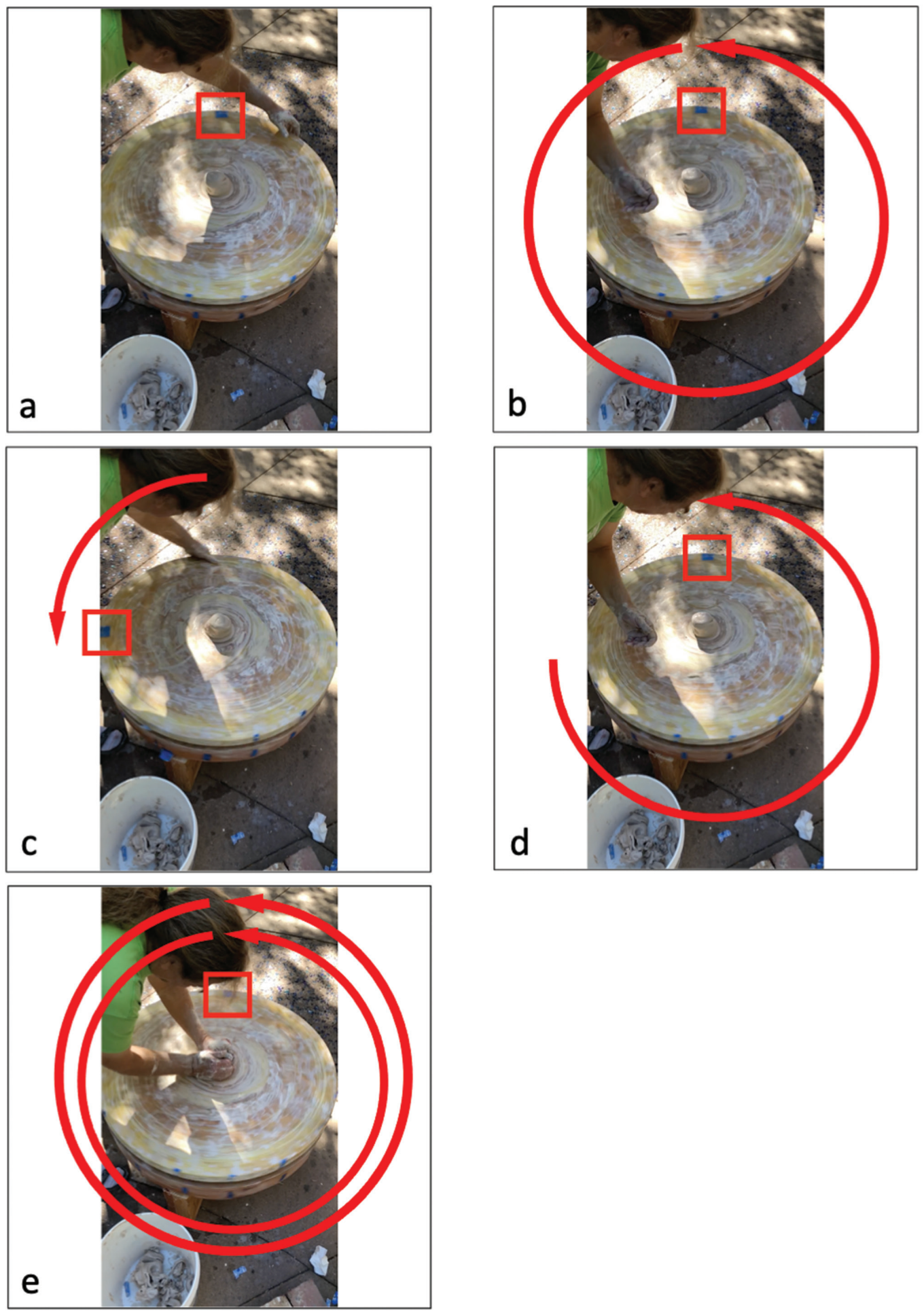

Figure 4. Five points during data collection. a: Starting frame. Use "s" key to begin. b: Wheel has made 1 rotation. Enter "1". c: Wheel has made quarter rotation. Enter " 0.25 ". d: Wheel has made three quarters of a rotation. Enter " 0.75 ”. e: Wheel has made two full rotations. Enter " 2 ".

easier if there is a high contrast mark on the wheelhead, such as masking tape.

The second step is to navigate to the web application and upload the video to the tool using the "Choose File" button. If the upload is successful, the video should appear in the box below the file selection button.
The third step in the process is the first of two preanalysis steps. Many recordings do not align exactly with the beginning and end of the wheel's use. Thus, before data collection begins, the appropriate point in the video must be reached. Using the " $n$ " key on the keyboard, progress through the video until the desired starting point is reached. 


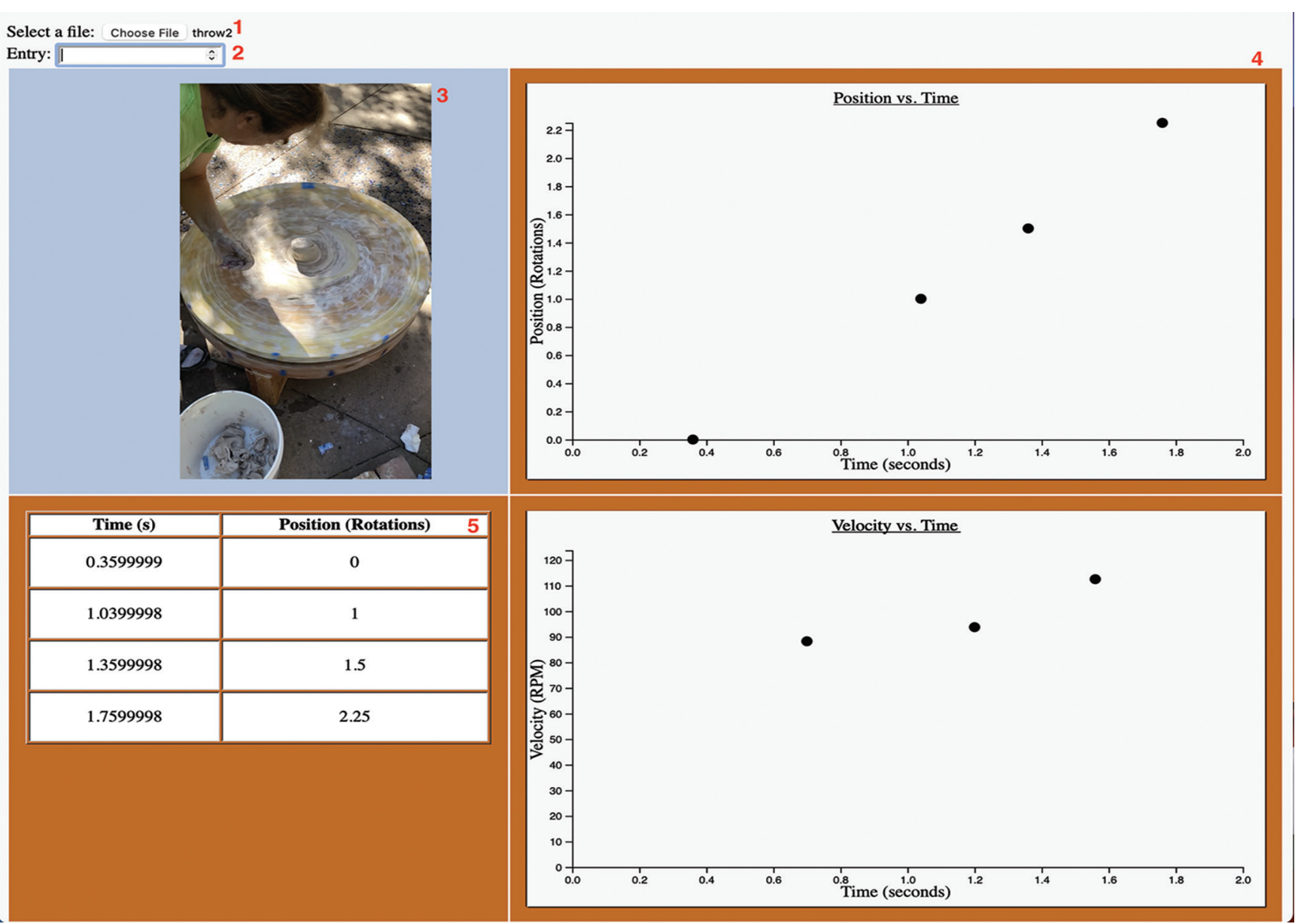

Figure 5. Web Application layout. 1 is the file selector, 2 is the entry field, 3 is the video being analysed, 4 are the position and velocity graphs, and 5 is the position table.

It is recommended that the visual mark on the wheelhead is aligned with a static element of the recording, such as the seat of the potter or the top of the frame. For the fourth step, once the desired starting point for analysis is on frame, press the "s" key to begin the analysis. This marks the start of data collection. The fifth step is the analysis stage. Again, using the " $\mathrm{n}$ " key, stream through the video until the wheel has made a sufficient amount of rotation. Once the wheel has made the desired rotation, enter the amount the wheel has turned into the text entry box. After entering the number of rotations, use the "n" key to submit the value and to continue to the next frame. Continue to use the " $n$ " key until another entry point. Into the text entry box, enter the number of rotations since the last entry. Do not enter the total amount the wheel has rotated. The example in Figure 4 shows how to determine what values to enter into the text box.

The accuracy of the analysis stage depends heavily on the accuracy of the user's determination of the amount of rotation. For this reason, it is highly suggested that the user does not input a new value for each frame. Instead, the user

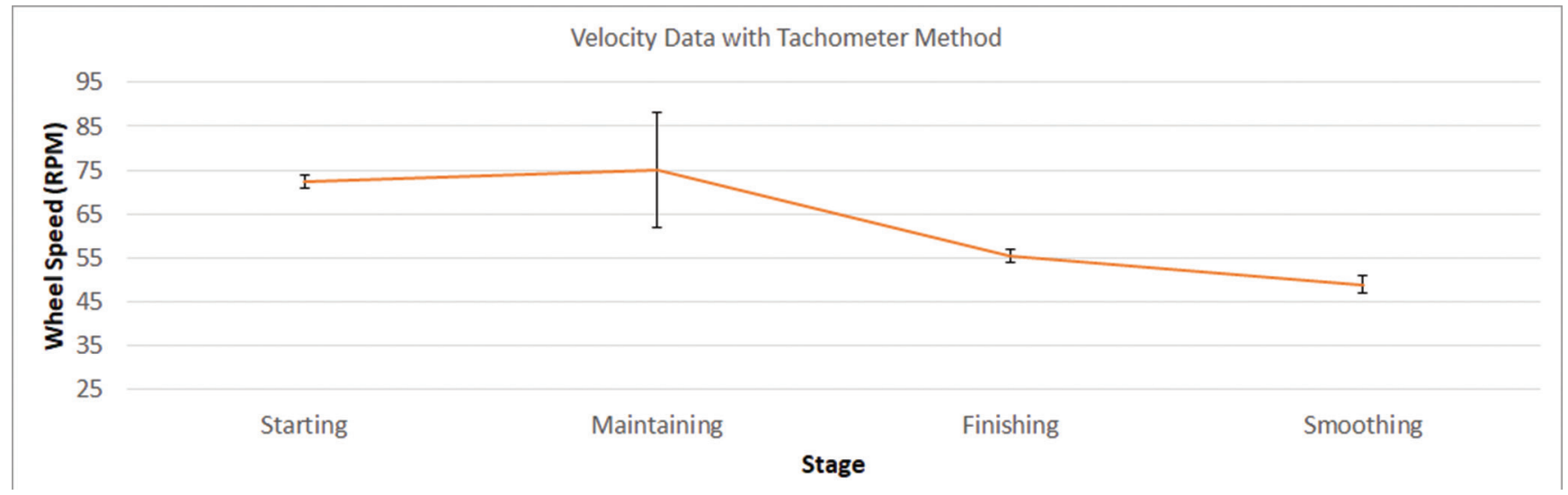

Figure 6. Velocity data gathered with tachometer method. Experienced Potter/Novice Spinner configuration. Vessel: closed form, H. $19 \mathrm{~cm}$. 


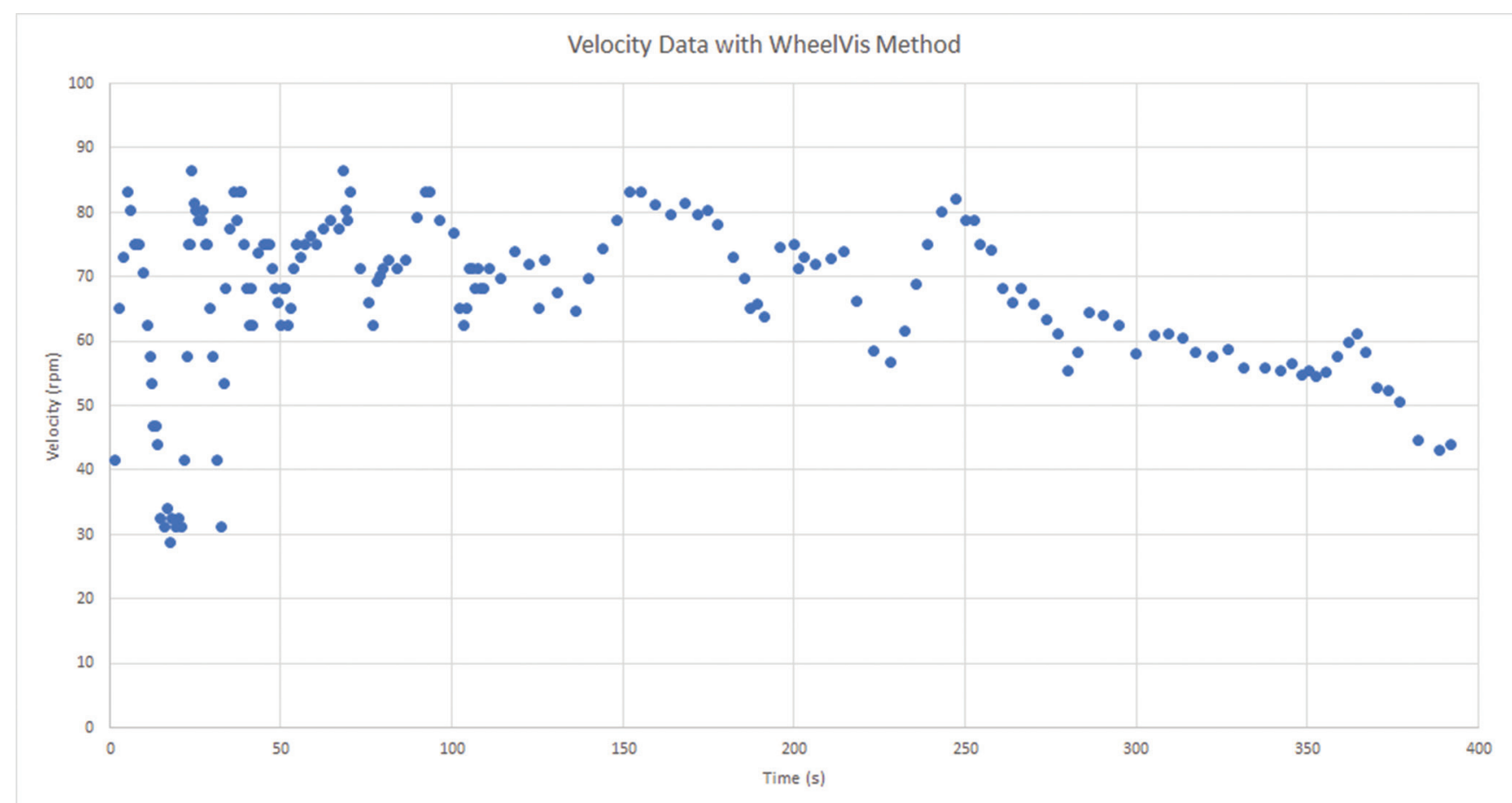

Figure 7. Velocity data gathered using WheelVis. Experienced Potter/Novice Spinner configuration. Vessel: closed form, H. $19 \mathrm{~cm}$.

should wait until there has been an easily distinguishable amount of rotation since the last entry. In the developer's experience, the best values are normally multiples of 0.25 . Rotation amounts less than 0.25 are subject to more estimation error and are thus less accurate.

Once data has been collected for the relevant video portion, using the "e" key exports the data to a .csv file. This file can then be opened in a preferred spreadsheet program and further analysis can be performed (Figures 4-5).

\section{Results}

To evaluate WheelVis, we compare its output with data collected using the digital tachometer method for one of the vessels created during the November 2017 throwing session (Figure 6). The videos analysed in this section are uploaded on the Ancient Greek Wheel Project's website (1tt. lab.arizona.edu/content/greek-wheel-project). The digital tachometer procedure split the throw into four segments, the

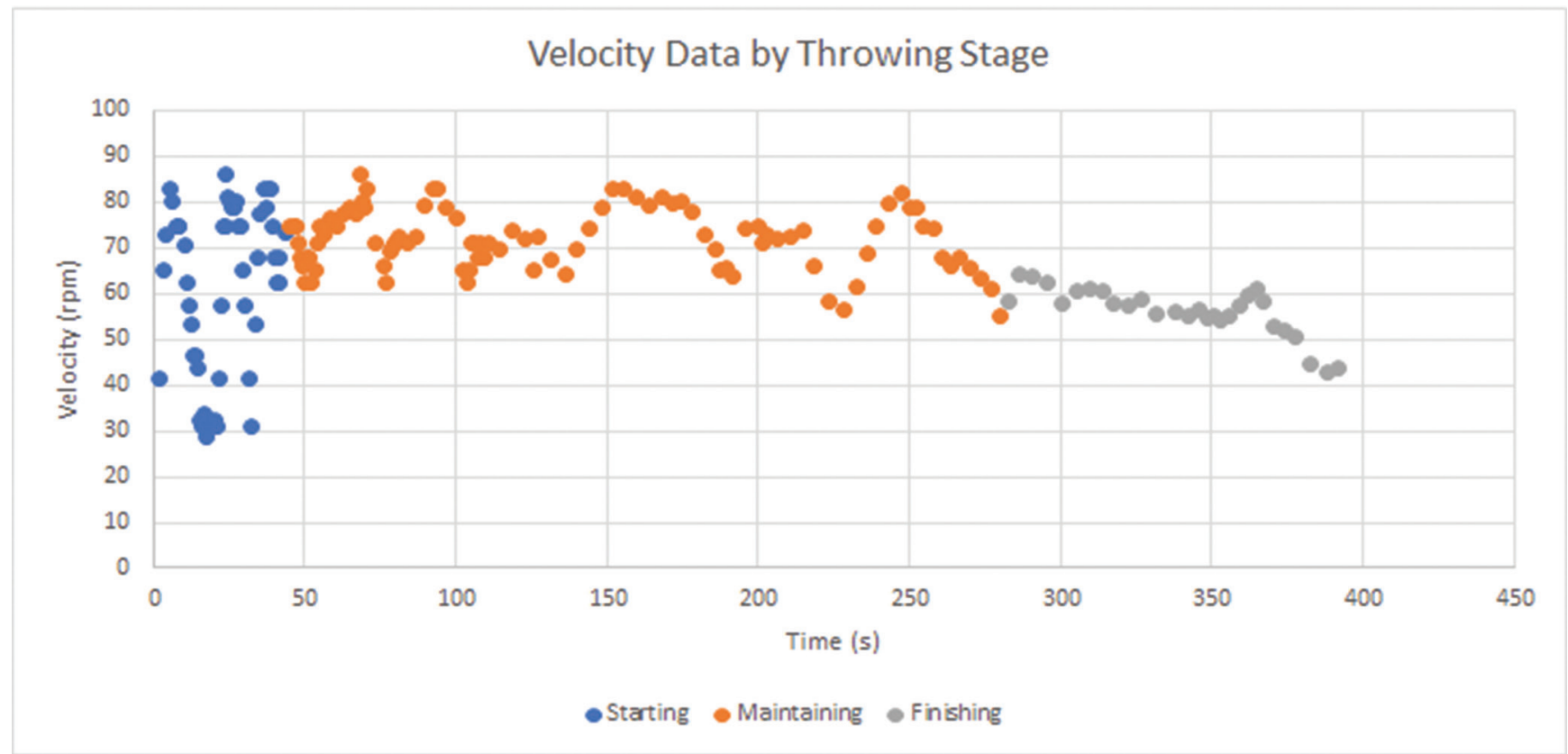

Figure 8. Velocity data partitioned, as a post-processing stage, by throwing stage; stage. Experienced Potter/Novice Spinner Configuration. Vessel: closed form, $\mathrm{H} .19 \mathrm{~cm}$. 
specific timestamps of which are not recorded. During the starting stage, velocities ranged from 71 to $74 \mathrm{rpm}$, while during maintaining, 62 to $88 \mathrm{rpm}$. During the finishing stage, it ranged 54 to $57 \mathrm{rpm}$, and then during smoothing 47 to $51 \mathrm{rpm}$ (Figure 6). We also recorded the same throwing session and used WheelVis to collect data on the same throwing session (Figure 7). Because the information was collected with higher granularity, it paints a clearer picture of the throwing process than the digital tachometer method. For example, between timestamps $50 \mathrm{~s}$ and $150 \mathrm{~s}$, we can see a jagged shape in the velocity. This correlates with the process of hand-spinning the wheel. The upward segments are where the spinner is speeding the wheel up, while the downward segments are the potter lifting and shaping the clay. Breaking up and colouring the velocity data based on the stage of the throwing session produces a very informative graph (Figure 8).

In the throwing session discussed above (Figures 6 and 7), the configuration was Experienced potter/Novice spinner. We also created a different chart to analyze the velocity data when only one experienced potter is involved (Figure 9). In this velocity data, we see more pronounced changes in the velocity, as the potter can only perform one task at a time.

\section{Discussion}

Previous researchers have addressed questions about rotational velocity with low-fidelity methods or without discussion of methods at all. Amiran and Shenhav describe their experiments with replica wheels, noting that they reached a maximum rotational velocity of $60 \mathrm{rpm}$, but do not provide details as to how they arrived at this figure (Amiran and Shenhav, 1984). In another study examining experimental replicas of ancient Egyptian potter's wheels, Powell provided more details about the method used. Powell recorded the amount of time required for 50-60 revolutions. Dividing the number of revolutions by the recorded times, Powell calculated the number of revolutions per minute (rpm), and averaged across four tests (Powell, 1995). Another example of a low-fidelity collection method can be found in Doherty's study on potter's wheels in ancient Egypt. Doherty used a similar method to Powell, counting the overall number of rotations and dividing by time to get an average rpm value. In contrast to Powell, Doherty used slowed down videos to perform the analysis (Doherty, 2014; 2015). This allowed Doherty to more accurately collect the average values. However, collecting fine-grained velocity data by hand is highly labour-intensive. Another attempt to collect velocity data from wheels is the previous work on the Ancient Greek wheel replica in Tucson. Thér and Toms (2016) used a laser tachometer to measure the velocity of the wheel. As we discussed above, the earlier method used on the Tucson wheel replica also involved the use of a digital tachometer to calculate ranges of speeds for each section of the throwing session (Hasaki, 2019).

While the laser tachometer method can accurately establish wheel velocity, it has a number of drawbacks compared to WheelVis. First, it requires additional technology. The tachometer and any peripheral cables, software, or computers

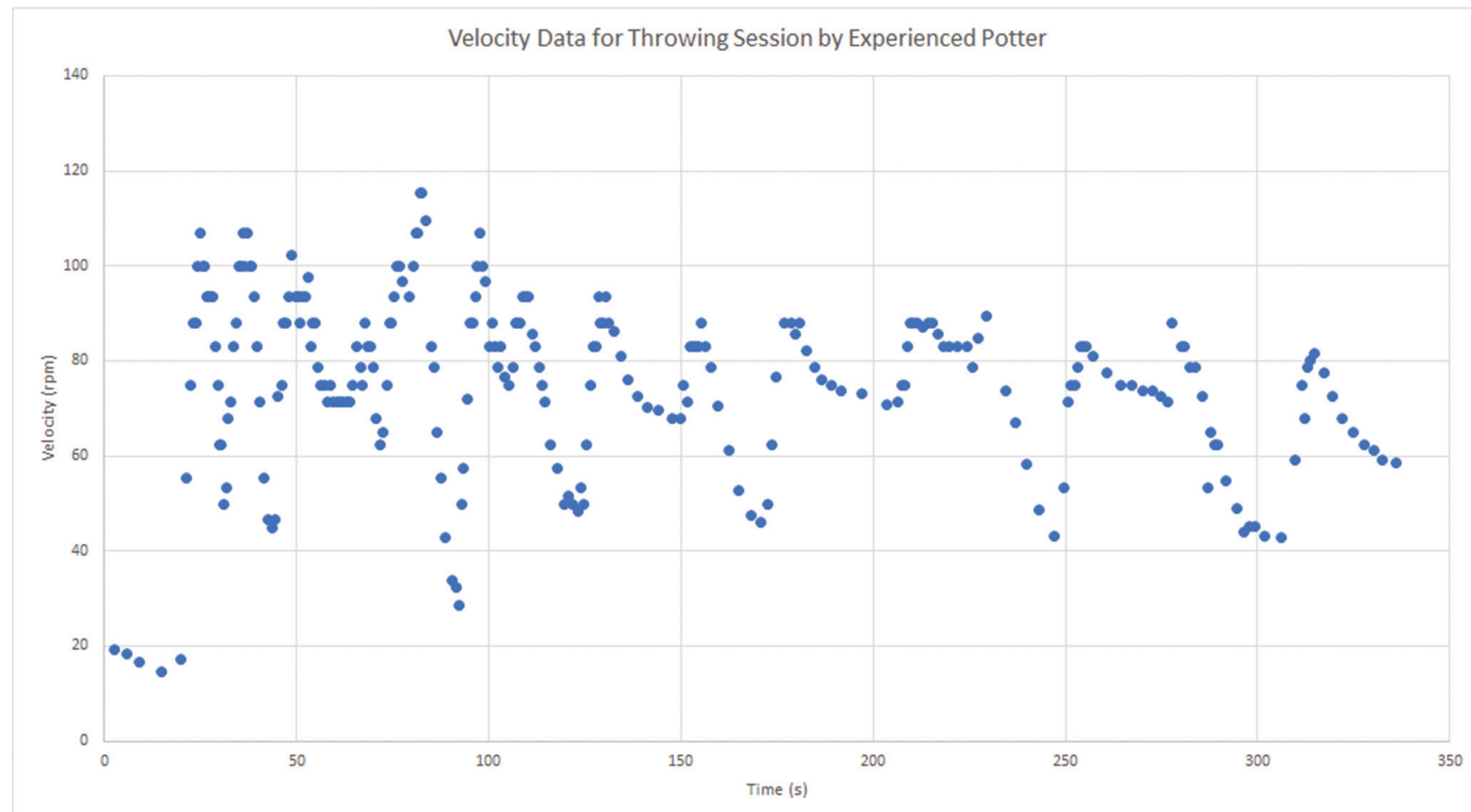

Figure 9. WheelVis velocity data collected for a throwing session where the experienced potter both spun the wheel and shaped the vessel. Vessel: closed form, H. $27 \mathrm{~cm}$. 
all must be prepared to collect velocity data. This is in contrast to WheelVis, which only requires the camera most people carry in their pocket as part of their phone. Second, its capabilities are limited by user knowledge and user error. For example, during our sessions, the tachometer user only recorded velocity ranges rather than velocity at regular intervals. Third, tachometer-collected data lacks verifiability. Using WheelVis, two researchers can confirm their velocity results by independently analysing the same video. Lastly, tachometer-collected data is single use. Video recordings capture much more than the velocity of the wheel. A video recording can capture the potter-spinner interactions, jostling of the wheel, and the sounds of the process, all of which are lost to the tachometer method.

\section{Conclusions}

Future development of WheelVis will proceed in two directions based on feedback from users. First, WheelVis will incorporate intelligent error detection to help users identify potential erroneous inputs.

Intelligent error detection will be incorporated by developing a prediction system. Using information about the previously provided inputs, the system will predict a range of likely inputs, and if the user's input falls outside of that range, it will warn the user that their input is unusual. For example, if the wheel has been consistently moving at $60 \mathrm{rpm}$, and an input suddenly changes the speed to $120 \mathrm{rpm}$, WheelVis will warn the user of a potential error. This addition will improve the accuracy and speed of using WheelVis because it helps identify errors as soon as they happen.

Second, WheelVis will incorporate context partitions automatically, allowing the user to break up a throwing session into different contexts based on relevant characteristics. Context partitions will enable real-time context labelling for recordings. This functionally is best explained through the third chart on screen. Consider the question of how velocity differs across different phases of the throwing process. One might expect certain phases, such as finishing, to have slower velocities than other phases, such as centring. With context partitioning, the user can mark different parts of the video as parts of different contexts. Then, this context data would be used to differentiate the velocity data for different phases. Another use of this feature will be to study how wheel contact changes with different potter-spinner configurations.

As we move forward with our experimental wheel program, we have identified areas that can be further explored: for example, after carefully measuring the weights of clay lumps placed on the Ancient Greek wheel replica, we started paying more attention on the weight of the pot while being formed on the wheel. In a project parallel to recording wheel speeds and timings, we also weighed a small group of Greek and South Italian vessels to estimate the original mass of clay a potter had to throw on the wheel in order to form a vessel in one or several pieces (Hasaki, 2019; 2021). A small aryballos $10 \mathrm{~cm}$ tall requires at least $0.16 \mathrm{~kg}$ of clay (post-trimming), a large-sized skyphos requires ca. $1.36 \mathrm{~kg}$

(cm)

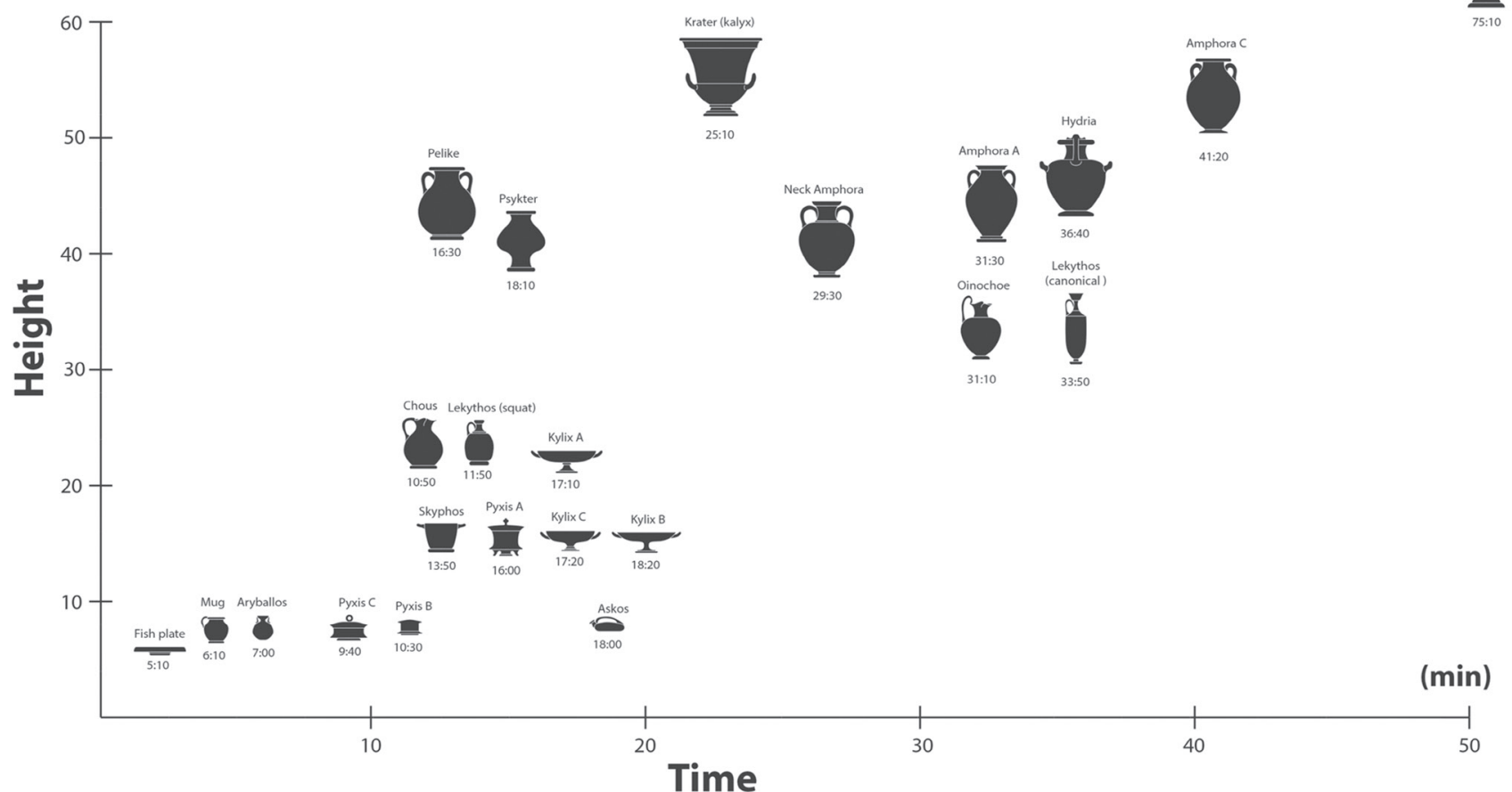

Figure 10. Estimated minimum throwing times for standard Athenian vases (courtesy of Yoji Horikoshi). The total time includes only active throwing and assembling the different parts of a vessel, not the intervals between these stages. Drawing by Eleni Hasaki and Yannis Nakas. 
of clay (in separate pieces), while a large krater at almost $1 \mathrm{~m}$ in height, requires an astounding amount of $24 \mathrm{~kg}$ of wet clay (this weight is after the neck, handles, and foot are joined together). If using the off-the-hump technique the potter could centre a larger mass of clay on the wheel (for example, $3 \mathrm{~kg}$ ), and throw about 10-15 aryballoi.

Another aspect is time: it will be extremely useful to develop a dataset of approximate time requirements to produce certain basic shapes from prehistoric and historic times. One set of experimental replicas of standard Athenian vases illustrates the variability of throwing times between small vessels (5-10 mins for a fish plate), elaborate drinking vessels (17-18 mins for different types of kylixes) to larger storage vessels (30-40 mins for amphoras) (Figure 10). Jeffra's detailed videos for throwing specific shapes (e.g., a Geometric pyxis) can also be a valuable resource when one collects all the throwing time data (https://www.youtube. com/watch? $v=22 \mathrm{dDqJHzJJ} 0$ ). Such estimates could help us better gauge the annual production of Greek ceramics, a perennially thorny topic in the scholarship, which relies mostly on the estimated survival rate of decorated ceramics, and on the estimated annual production rate of distinguishable vase-painters (Sapirstein, 2013; 2020; Stissi, 2016; 2020).

The ever-expanding field of potter's wheel research can definitely benefit from interdisciplinary approaches. We hope that fine-grained information on the wheel's performance through the study of its velocity and the WheelVis application can complement current research programs which focus on the potter's hand positions over time (Gardon and Roux, 2019), or on the shape contour of a vessel during the forming phase (Roux et al., 2018). An equilibrium of emphasis on the potter, the pot, and the wheel will help us better understand their interdependence.

\section{Acknowledgements}

We would like to thank the conference organisers, especially Caroline Jeffra for welcoming us to the conference. We are deeply indebted to Andy Iventosh, Joni Pevarnik and Michael Schiffer for throwing vessels on the experimental wheel, Dan Pont for his research design and critical input in the pre 2017 and 2017 experiments, and to Ruben Moreno (at Arizona State Museum) for adjusting the height of the wheel replica. We express our appreciation to Alan R. May for always providing technical expertise. Financial support was provided by the School of Anthropology and the Laboratory for Traditional Technology at the University of Arizona. We would like to dedicate this article to Dr. Anna Lemos, Professor Emerita at the University of Athens, Greece for introducing one of us (Eleni Hasaki) to the fascinating world of pottery.

\section{References}

AMIRAN, R., and SHENHAV, D., 1984: Experiments with an ancient potter's wheel. In: P. Rice, ed. Pots and Potters. Current Approaches in Ceramic Archaeology. Berkeley: Cotsen Institute of Archaeology, pp. 107-112.

BERG, I., 2007: Meaning in the making: the potter's wheel at Phylakopi, Melos (Greece). Journal of Archaeological Anthropology, 26(2), 234 252.

BERG, I., 2015: Potting skill and learning networks in Bronze Age Crete. In: G. Gauss, G. Klebinder-Gauss, C. von Rüden, eds. The Transmission of Technical Knowledge in the Production of Ancient Mediterranean Pottery. Proceedings of the International Conference at the Austrian Archaeological Institute at Athens, $23^{\text {rd }}-25^{\text {th }}$ November 2012. Vienna, pp. 17-35.

CHOLEVA, M., 2012: The first wheel-made pottery at Lerna. Wheelthrown or wheel-fashioned? Hesperia, 81(3), 343-381.

CHOLEVA, M., 2020: Travelling with the potter's wheel in Early Bronze Age Aegean, Annual of the British School at Athens, 115, 59-104.

COURTY, M.A., and ROUX, V., 1995: Identification of wheel throwing on the basis of ceramic features and microfabrics. Journal of Archaeological Science, 22, 17-50.

CUOMO DI CAPRIO, N., 2017: Ceramics in Archaeology: From Prehistory to Medieval Times in Europe and the Mediterranean: Ancient Craftsmanship and Modern Laboratory Techniques. Roma: L'Erma di Bretschneider.

DOHERTY, S.K., 2014: Throwing Pottery with a Replica Ancient Egyptian Potter's Wheel. (https://www.youtube.com/watch?v=tayUODG6iA0; accessed February 5, 2021)

DOHERTY, S.K., 2015: Origins and Use of the Potter's Wheel in Ancient Egypt. Oxford: Archaeopress.

EITELJORG, H., 1980: The fast wheel, the multiple-brush compass and Athens as home of the Protogeometric style. American Journal of Archaeology, 84(4), 445-452.

EVELY, D., 2000: Minoan Crafts: Tools and Techniques 2. Studies in Mediterranean Archaeology, 92, Göteborg: P. Aström.

EVELY, D., and MORRISON, J.E., 2010: The Minoan potter's wheel: a study in experimental archaeology. In: P. Matthiae, F. Pinnock, L. Nigro, and N. Marchetti, eds. Proceedings of the $6^{\text {th }}$ International Congress on the Archaeology of the Ancient Near East. Wiesbaden: Harrassowitz, pp. 283-288.

GANDON, E., and ROUX, V., 2019, Cost of motor skill adaptation to new craft traits: experiments with expert potters facing unfamiliar vessel shapes and wheels. Journal of Anthropological Archaeology, 53, 229239.

GOROGIANNI, E., ABELL, N., and HILDITCH, J., 2016: Reconsidering technological transmission: the introduction of the potter's wheel at Ayia Irini, Kea, Greece. American Journal of Archaeology, 120(2), 195-220.

HADJIDIMITRIOU, A., 2005: Parastásis ergastirion kai emporiou stin ikonographía ton klasikón khrónon. Athens: The Archaeological Society at Athens.

HASAKI, E., 2011: Crafting spaces: archaeological, ethnographic and ethnoarchaeological studies on spatial organization in pottery workshops in Greece and Tunisia. In: M. Lawall, and J. Lund, eds. Pottery in the Archaeological Record: Greece and Beyond. Acts on the International Colloquium held at the Danish and Canadian Institutes in Athens, 20-22 June 2008. Aarhus: Aarhus University Press, pp. 12-28.

HASAKI, E., 2012: Craft apprenticeship in ancient Greece: reaching beyond the masters. In: W. Wendrich, ed. Archaeology and Apprenticeship: Acquiring Body Knowledge in the Ancient World. Tucson: University of Arizona Press, pp. 171-202.

HASAKI, E., 2019: Potters and their wheels in ancient Greece: skills and secrets in communities of practice. In: M. Denti, and M. Villette, eds. Archéologie des espaces artisanaux. Fouiller et comprendre les gestes des potiers. Rennes : Université de Rennes, pp. 297-314.

HASAKI, E. 2021. Potters at Work at Ancient Corinth: Industry, Religion, and the Penteskouphia Pinakes (Hesperia Suppl. 51). American School of Classical Studies at Athens, Princeton, N.J.

JEFFRA, C., 2011: The Archaeological Study of Innovation: An Experimental Approach to the Pottery Wheel in Bronze Age Crete and Cyprus. Unpublised thesis (Ph.D), University of Exeter.

JEFFRA, C., 2013: A re-examination of early wheel potting in Crete. Annual of the British School at Athens, 108, 31-49.

KNAPPETT, C., 1999: Technology and innovation in pottery forming technology: wheel-Throwing at Middle Minoan Knossos. Annual of the 
British School at Athens, 94, 101-129.

KNAPPETT, C., 2004: Technological innovation and social diversity at Middle Minoan Knossos. In: C. Cadogan et al., eds. Knossos: Palace, City, State. Proceedings of a Conference in Herakleion Organized by the British School at Athens and the 23 $3^{\text {rd }}$ Ephoreia of Prehistoric and Classical Antiquities of Herakleion November 2000, for the Centenary of Sir Arthur Evans' Excavations at Knossos. London: British School at Athens, pp. 257-265.

KNAPPETT, C., and VAN DER LEEUW, S., 2014: A developmental approach to ancient innovation: the potter's wheel in the Bronze Age East Mediterranean. Pragmatics and Cognition, 22(1), 64-92.

LANGDON, S., 2013: Children as learners and producers in early Greece. In: J. Evans Grubbs et al., eds. Oxford Handbook of Childhood and Education in the Classical World. Oxford: Oxford University Press, pp. 172-194.

MORRISON, J.E., and PARK, D.P., 2007-2008: Throwing small vessels in the LM 1B Mochlos potter's pit. Kentro. The Newsletter of the INSTAP Study Center for East Crete, 10, 6-10.

POWELL, C., 1995: The nature and use of ancient Egyptian potters' wheels. In: B. J. Kemp, ed. Amarna Reports, 6, London: Egypt Exploration Society, pp. 309-335.

ROTROFF, S., 2006: Agora XXXIII. Hellenistic Pottery: The Plain Wares. Princeton: American School of Classical Studies.

ROUX, V., BRIL, B., and KARASIK, A., 2018: Weak ties and expertise: crossing technological boundaries. Journal of Archaeological Method and Theory, 25, 1024-1050.

ROUX, V., and CORBETTA, D., 1989: The Potter's Wheel. Craft Specialization and Technical Competence. New Delhi: South Asia Books.

ROUX, V., and COURTY, M.A., 1998: Identification of wheel-fashioning methods: technological analysis of $4^{\text {th }}-3^{\text {rd }}$ millennium BC Oriental ceramics. Journal of Archaeological Science, 25, 747-763.

ROUX, V., and JEFFRA, C., 2015: The spreading of the potter's wheel in the ancient Mediterranean. In: W. Gauss, G. Klebinder-Gauss, C. Von Rüden, eds. The Transmission of Technical Knowledge in the Production of Ancient Mediterranean Pottery. Proceedings of the International Conference at the Austrian Archaeological Institute at Athens, 23 $3^{\text {rd }}-25^{\text {th }}$
November 2012. Wien: Austrian Archaeological Institute, pp. 165-182.

ROUX, V., and de MIROSCHEDJI, P., 2009: Revisiting the history of the potter's wheel in the Southern Levant. Levant, 41(2), 155-173.

SAPIRSTEIN, P., 2013: Painters, potters, and the scale of the Attic vasepainting industry. American Journal of Archaeology, 117, 493-510.

SAPIRSTEIN, P., 2020: Productivity of Athenian vase-painters and workshops. In: E. Hasaki and M. Bentz, eds. Reconstructing Scales of Production in the Ancient Greek World: Producers, Processes, Products, People. Heidelberg: Propylaeum, pp. 81-96.

SCHREIBER, T., 1983: The turn of the wheel. Greek Vases in the J. Paul Getty Museum, 1, 149-153.

SCHREIBER, T., 1999: Athenian Vase Construction: A Potter's Analysis. Malibu: J. Paul Getty Museum.

STISSI, V., 2002: Pottery to the People. The Production, Distribution, and Consumption of Decorated Pottery in the Greek World in the Archaic Period (650-480 BC). Unpublished thesis (Ph.D), University of Amsterdam.

STISSI, V. 2016: Minor artisans, major impact? In: N. Eschbach and S. Schmidt, eds., Töpfer, Maler, Werkstatt: Zuschreibungen in der griechischen Vasenmalerei und die Organisation antiker Keramikproduktion, CVA Beih. 7, Munich, pp. 47-53.

STISSI, V., 2020: From counting pots to counting people: assessing the scale of Athenian pottery production and its impact on workshop staff. In: E. Hasaki, and M. Bentz, eds. Reconstructing Scales of Production in the Ancient Greek World: Producers, Processes, Products, People. Heidelberg: Propylaeum, pp. 97-108.

THÉR, R., and TOMS, P., 2016: Quantification of the orientation and alignment of aplastic components of a ceramic body as a method for distinguishing among various means of using a rotational device in pottery forming. Journal of Archaeological Science: Reports, 9, 33-43.

VIDALE, M., 2002: L'idea di un lavoro lieve. Il lavoro artigianale nelle immagini della ceramica greca tra VI e IV secolo a.C. Saltuarie dal laboratorio del Piovego, 5, Padova: Imprimitur.

WILLIAMS, W., 2009: Picturing potters and painters. In: O. Palagia and J.H. Oakley, eds. Athenian Potters and Painters II. Oxford: Oxbow Books, pp. 307-317. 
